\title{
A biocultural approach to firewood scarcity in rural communities inhabiting arid environments in Patagonia (Argentina)
}

Daniela Morales ${ }^{1}$, Soledad Molares ${ }^{1}$, Ana Ladio ${ }^{2, *}$

\begin{abstract}
From an ecological perspective the use of firewood species implies chronic pressure on wood vegetation, but from a biocultural point of view the implications are more systemic and complex. The objective of this work was to make a comprehensive analysis of the biocultural characteristics of firewood plants used by two rural communities in arid Patagonia, considering their cultural attributes, value as fuel and ecological persistence traits against continuous extraction. The study was carried out with 33 participants, and ethnobotanical information was collected on the use, preferences and attributes of species used, together with ecological information obtained from a bibliographical review. Of the 28 firewood species registered, 12 stood out as being preferred for firewood use. Native plants $(66.6 \%)$ were generally preferred to exotic species (33.3\%). Several ecological features of the preferred plants were noted, such as vegetative regeneration (43\%), high geographical distribution (36\%) and nitrogen fixation $(18 \%)$. Most of these species also present a high level of utilitarian versatility, and are therefore multipurpose resources. These characteristics, of both ecological and cultural importance, should be key criteria for the selection of species for forestry programmes related to the development of firewood plantations.
\end{abstract}

Keywords: Firewood Plantations, Intercultural Response, Sustainability, Self-sufficiency

\footnotetext{
1 CIEMEP, CONICET, Universidad Nacional de la Patagonia SJB. Roca 780. Esquel (9200). Chubut. Argentina.

2 INIBIOMA, CONICET, Universidad Nacional del Comahue, CRUB. Quintral 1250. SC de Bariloche (8400). Río Negro. Argentina.
}

* Corresponding author. $\mathrm{E}$ E-mail address: ahladio@gmail.com

\section{INTRODUCTION}

In rural communities a whole culture surrounds firewood plants, and an important legacy of knowledge and practices relating to their use has been accumulated over time
(Arre et al. 2015). Several studies have revealed that selection of these plants is based on appreciation of certain biophysical attributes (Chettri and Sharma 2007; Tabuti et al. 2003), which correspond closely to calorific value, ease of ignition and the 
production of long-lasting embers, and are also associated with ecological and cultural factors (Cardoso et al. 2015; Ramos et al. 2008).

It has also been shown in international literature that some firewood plants selected by locals present certain ecological features, such as their capacity to produce new shoots, which is valued and taken advantage of by settlers for continuous and diversified use (Abbot and Lowore 1999; May 2013). This is a key aspect in arid environments where the establishment of plants through seeding is limited, and the persistence of shrubs is crucial due to the absence of trees or other fuelwood supplies (Barchuk et al. 2006).

In NW arid Patagonia there are many rural Creole and Mapuche-Tehuelche populations which depend on woody plant resources and have developed diverse practices to deal with their scarcity (Ladio and Lozada 2004), such as multiple and diverse use of the environment, management of water bodies and pasture succession (Ladio 2013; Richeri et al. 2013). Interwoven into these practices are rules and social codes that ensure these resources are used in accordance with local needs, mainly involving guidelines related to the care and renovation of natural elements in the surroundings (Aigo and Ladio 2016; Ladio and Molares 2016).

In particular, in NW Patagonia, arid and semi-arid shrublands are considered highly fire resilient communities, composed of species that can reproduce vegetatively from root crown, trunk bases or rhizomes (Nuñez and Raffaele 2007). This strategy permits the system to reach biomass and composition just a few years after disturbance, giving these shrublands extraordinary resilience. The ecological persistence traits of species that make up this landscape could therefore be a key factor against the chronic pressure of wood extraction.

Several investigations in Patagonia (Armesto et al. 2001; Citarella 1995) have found that practices developed in traditional Patagonian cultures for the use of natural resources demonstrate a strong sense of respect for life. This can be seen, for example, in the principle of reciprocity, which entails not only moderation in extraction but also promotion of growing conditions afterwards. For this reason, we consider that certain elements of the ecological profile of the plants used, such as resprouting capacity, rapid growth, wide geographical distribution and nitrogen fixing capacity (a characteristic that increases their ability to colonise poor soils with signs of erosion) may be selectively valued and taken advantage of by these communities.

The selection and management of useful resources, that is, their conceptualization as a cultural asset and methods of use, are part of a society's local ecological knowledge (LEK) (Toledo 1992; Berkes 1999; Gunderson and Holling 2002). This LEK constitutes an integral element of local culture, orienting inhabitants' action strategies and their administration of the environment (Berkes 1999). LEK is expressed in different ways, such as inhabitants' attitudes and philosophies, and is also clearly reflected in everyday practices. Therefore, within the framework of this Mapuche cosmovision which integrates culture and environment (Molares and Ladio 2012), it seems likely that the use of firewood plants reflects a biocultural approach where these dimensions merge.

However, the impoverishment of rural families, the lack of alternative energy sources and efficient stoves, plus poor thermal insulation in dwellings, have given 
rise to high use pressure on wild firewood resources (Cardoso et al. 2015; Izquierdo et al. 2009; Yao and Bae 2008). These processes combined with others such as overgrazing, lead to chronic pressure on wood plants, resulting in, from a conservationist perspective, considerable damage such as erosion, loss of soil organic matter and overharvesting of some native plant species (Armesto et al. 2001; Izquierdo et al. 2009; Kebede et al. 2015).

Increasing attention has been paid by Government and Multilateral institutions to creating synergies with local inhabitants, in search of solutions (Tengö et al. 2014). However, these technicians have generally communicated a vision of rural dwellers' use of the biota as being associated with patterns condemned as over-exploitative, and the external solutions imposed have not taken local opinion into account (Cardoso and Ladio 2011; Szymañsk 2012). The implementation of firewood plantations which complement traditional gathering practices has been one of the strategies most recommended to alleviate damage in this arid Patagonian environment (Izquierdo et al. 2009), as in many other places throughout the world (May 2013; Yao and Bae 2008).

Nevertheless, these projects often fail due to a lack of community involvement, the external project not taking into account local families' viewpoints or botanical-ecological particularities which are valued by inhabitants (Cardoso and Ladio 2011). Local knowledge of firewood plants is essential for the development of these programmes, given that it includes detailed information on the species with the best qualities in terms of persistence against continuous extraction, resistance to limiting environmental factors (water, soil), their contribution to erosion control and their cultural value.
Consequently, an integrated approach to firewood use must involve consideration of the system as both a biocultural (Maffi 2001) and intercultural (Pérez-Ruiz and ArguetaVillamar 2011) framework - in other words, a perspective which analyses the biologicalecological characteristics of the firewood species in question, together with the significance, uses and management of these species by inhabitants. Most important, however, is the incorporation of motivating factors and interests of the players in sustaining and preserving the biocultural system, thus orienting collective solutions to environmental change and the scarcity of subsistence resources (Gómez-Baggethun et al. 2012; Trillo et al. 2014; Vandebroek et al. 2011).

The objectives of our work were: 1) To determine which firewood species used by two communities living on the arid lands of Patagonia, Argentina, have the highest use consensus. 2) To establish, according to the inhabitants' vision, which of these species are preferred, and identify which ecological and cultural attributes are valued in the choice of firewood. 3) To define, according to literature on ecology, which of these species have ecological persistence traits against wood extraction. 4) To carry out a biocultural analysis of the species involved, and ascertain which ones possess the best attributes for inclusion in local biocultural conservation plans. This intercultural initiative requires the integration of two knowledge systems, scientific and local, which are given the same epistemological status, so that all the different perspectives are taken into account in dealing with the problem of firewood shortage. 


\section{MATERIAL AND METHODS}

The study area is situated on the Patagonian plateau in the northwest of Chubut province, Argentina, in the Gualjaina locality $\left(42^{\circ} 4^{\prime} \mathrm{S}\right.$ and $\left.70^{\circ} 32^{\prime} \mathrm{W}\right)$ and the neighbouring community of Paraje Costa del Lepá (42 $34^{\circ}$ 'S and $\left.71^{\circ} 03^{\prime} \mathrm{W}\right)$ (Figure 1).

Both communities are situated in the Cushamen department, and are surrounded by the Lepá, Gualjaina and Chubut rivers. There are 1183 inhabitants (INDEC 2010) in the Gualjaina locality and approximately 84 families live in Paraje Costa del Lepá. In both communities inhabitants are closely related in terms of work and family, the majority being of Mapuche and Creole origin (ECPI 2007). Economic activities are based mainly on sheep and goat breeding, and to a lesser extent, the sale of handcrafts to tourists and cultivation of Solanum tuberosum L., Cucurbita maxima Duchesne, Brassica oleraceae L., Daucus carota L., and Raphanus sativus L., amongst other species.

These communities lie in grass-shrub steppe, where plant coverage is approximately 50\%, and dominated principally by the shrubs Mulinum spinosum (Cav). Pers., Senecio filaginoides DC.,
Nassauvia axillaris (Lag. ex Lindl.) D. Don., Berberis microphylla G. Forst., Schinus johnstonii F.A. Barkley and the Poaceae Poa spp. and Pappostipa spp. The least frequent species are trees, both native species (Salix humboldtiana, Discaria spp.) and exotic (mainly Salix spp.), whose distribution is limited to the coasts of rivers and streams.

Average annual precipitation in the region is approximately $119 \mathrm{~mm}$, and average temperatures fluctuate between $17.5^{\circ} \mathrm{C}$ in summer and $2.6^{\circ} \mathrm{C}$ in winter (Mereb 1990).

As in other communities in the region, these populations have suffered marked processes of colonization and marginalisation since the "desert campaign" (military invasions which took place between 1878 and 1885), and have also been affected by the "standardising" State education system and the influence of different public policies which have threatened their cultural diversity (Finkelstein and Méndez 2008).

In participative workshops carried out with locals, they expressed both their concern about the sustainability of the firewood resource and their interest in its cultivation and the use of plant nurseries for this purpose.

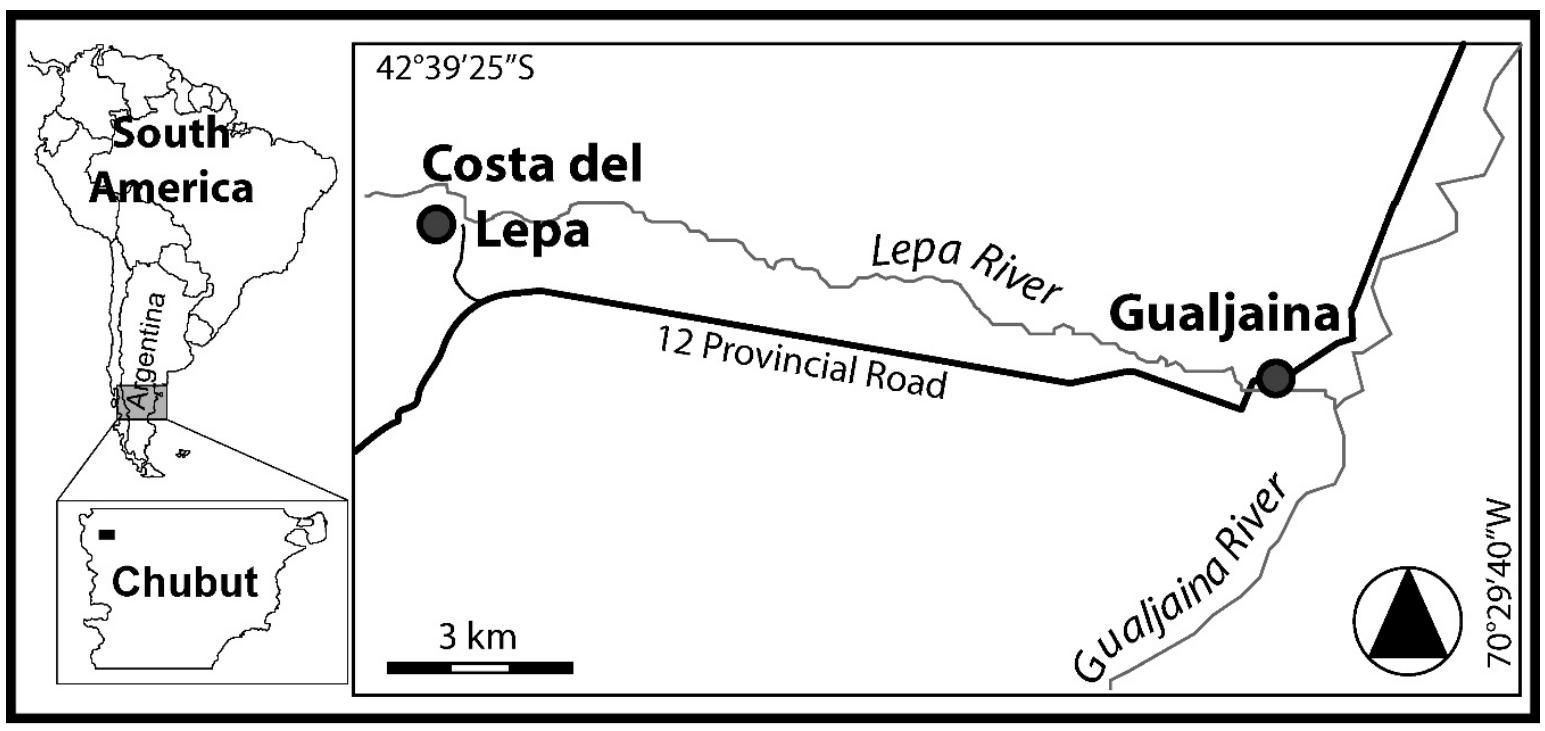

Figure 1. Location of the study area in NW Chubut province, Argentina. 


\section{Data collection}

Before carrying out this study, previous informed consent was obtained from 33 rural families (International Society of Ethnobiology 2006). The population sample was composed of household heads, 11 men and 22 women ranging in age from 30 to 90 , with a mean age of 59.8. The ethnobotanical information was collected through open and semi-structured interviews and free listing. This protocol was used to evaluate the richness of firewood plants utilized by inhabitants, the preferred species and their attributes. Also, during the interviews additional reputed uses of firewood species were recorded (medicinal, edible, dyeing uses, etc).

In addition to individual interviews, three workshops were held using participatory rural appraisal techniques, with 15-20 settlers at a time, to discuss ideas about firewood conservation. This discursive aspect of LEK was complemented with other ethnobotanical techniques, such as participant observation and open talks. Field walks were also carried out with key informants for recognition of mentioned plants. Samples of botanical material collected were herborised and placed in the Esquel Mountain and Patagonian Steppe Research Center (CIEMEP).

Taxonomic identity, biogeographic origin and life forms of the species were classified according to the Darwinion Institute (www.darwinion.gov.ar) vascular plant catalogue and Tropicos (www.tropicos.org).

The ecological traits which favour persistence against firewood extraction, such as resprouting capacity, nitrogen fixation and the ability to become established in a wide range of environmental conditions, were estimated by means of a bibliographical review, following the Scielo (www.scielo.org),

ScienceDirect (www.sciencedirect.com) and Scopus (www.scopus.com) databases. This investigation involved reviewing approximately 20 studies, found using the scientific names of all the species as key words in search engines.

\section{Data analysis}

Species and botanical family richness was estimated using the total number of species and families mentioned by all the informants. Use consensus (UC) amongst inhabitants was analysed for the total number of firewood species as a measure of their cultural importance, taking into account the frequency of cites of each species in relation to the total number of informants, expressed as a percentage (Molares and Ladio 2012). The plants recognised by inhabitants as preferred firewood species were identified, and for these species a preference value was estimated, calculated as a relative frequency (Ramos et al. 2008).

Use versatility (UV) of the preferred firewood species was determined, using the formula UV $=\sum U V$ si/ni (Phillips and Gentry 1993), where UVsi = the number of uses recorded by informant i for species s, and ni $=$ the number of informants who mention species $i$. The value of UV ranges from 1 (species used exclusively for firewood) to 2 (species with an average of 2 uses). Both UV and UC are commonly used to explain the cultural importance of species (Richeri et al. 2013).

In addition, the attributes of the firewood species mentioned by inhabitants were put into etic categories, such as calorific value (high, low), ash production (high, low), smoke emission (high, low), ease of ignition (inhabitants use the species for lighting a fire: yes, no), availability of the resource (the 
species is easily accessible and available for gathering: yes, no) and long-lasting embers (the species can burn for some hours: yes, no).

The ecological traits of the firewood species identified from the literature were categorised according to biogeographic origin (native or exotic to Patagonia), and to the characteristics we consider important as ecological persistence traits, such as growth habit (tree or shrub), predominant form of regeneration (vegetative or seed), nitrogen fixation (presence or absence) and extent of geographical distribution (restricted or extensive), in relation to the capacity of combustible species to develop in diverse climatic and edaphic conditions in the Patagonian region, according to Correa (1971, 1984).

Total richness of native species was compared with that of exotic species using the binomial test ( $p<0.05)$; richness of preferred native species and preferred exotic species was compared in the same way.

A correspondence analysis (CA) was carried out to distinguish different groupings of the firewood species cited (rows) and their ecological and cultural attributes (columns). In order to obtain better representation of the statistical analysis, firewood species with UC values of less than $6.06 \%$ were excluded (only 20 species were cited by two or more informants).

Statistical analyses were carried out using the InfoStat Statistical Package programme (Di Rienzo et al. 2016) and SPSS 22.0.

\section{RESULTS}

\section{Firewood species}

The inhabitants of Costa del Lepá and Gualjaina gather a total of 28 firewood species, belonging to 24 genera and 14 botanical families (Table 1). Of the total number of plants, $75 \%$ are native to Patagonia (Binomial test, $p=0.02$ ). The highest values of UC were found for Salix sp. "sauce" (87.9\%), S. johnstonii "molle" (78.8\%), Populus alba "álamo" (54.5\%) and N. axillaris "uña de gato" (54.5\%). Gathering of the firewood resource consists mainly in the extraction of fallen dead branches, prunings from peridomestic or municipal forest plantations, and in some cases total extraction of the plant or tortuous and voluminous subterranean organs (i.e., $S$. johnstonii, Retanilla patagonica, Prosopis denudans var. patagonica). A mixture of dead and green wood is generally used to improve the quality and duration of the fire. These species are employed principally for heating and cooking, some being used only for starting the fire, while the plants that produce persistent embers are used to maintain combustion for a long period of time. Some of the species play a direct or indirect role in the dietary customs of the families, since smoking with different species of firewood gives different flavours to the food (i.e., $N$. axillaris, $S$. filaginoides). Others have symbolic connotations, generally aromatic species used to perfume dwellings, mainly for reasons of wellbeing or "driving out evil spirits" (i.e., Acantholippia seriphioides).

\section{Preferred firewood species}

The 12 firewood species mentioned as the most preferred belong mainly to the families Salicaceae (3 species), Fabaceae (2 species) and Rhamnaceae (2 species). With regard to biogeographic origin, $66.6 \%$ are native species (Binomial test $p=0.38)($ Table 1). S. johnstonii (48.5\%), Salix sp. (27.3\%), and $P$. alba $(15.1 \%)$ present the highest preference values, concomitant with the 
Table 1. Plants used and preferred by inhabitants of Costa del Lepá and Gualjaina, Patagonia, Argentina, and their biocultural characteristics (ecological and ethnobotanical aspects). Abbreviations: $\mathrm{BO}=$ Biogeographic origin (N=Native, $\mathrm{E}=$ Exotic); $\mathrm{H}=$ Growth habit $(\mathrm{Sh}=$ shrub, $\mathrm{T}=$ tree); $\mathrm{UC}=\mathrm{Use}$ consensus; $\mathrm{PV}=$ Preference value.

\begin{tabular}{|c|c|c|c|c|c|}
\hline $\begin{array}{l}\text { Salix sp.* } \\
\text { Salicaceae } \\
\text { Sauce }\end{array}$ & $E$ & $\mathrm{~T}$ & 87.9 & 27.3 & $\begin{array}{l}\text { Fodder, structural } \\
\text { materials, } \\
\text { provision of } \\
\text { shelter }\end{array}$ \\
\hline $\begin{array}{l}\text { Schinus johnstonii F.A. Barkley.* } \\
\text { Anacardiaceae } \\
\text { Molle }\end{array}$ & $\mathrm{N}$ & Sh & 78.8 & 48.5 & $\begin{array}{l}\text { Food, fodder, } \\
\text { dyes, medicine }\end{array}$ \\
\hline $\begin{array}{l}\text { Populus alba L.* } \\
\text { Salicaceae } \\
\text { Alamo plateado }\end{array}$ & $\mathrm{E}$ & $T$ & 54.5 & 15.1 & $\begin{array}{l}\text { Fodder, structural } \\
\text { materials, } \\
\text { provision of } \\
\text { shelter }\end{array}$ \\
\hline $\begin{array}{l}\text { Nassauvia axillaris (Lag. ex Lindl.) D. } \\
\text { Don* } \\
\text { Asteraceae } \\
\text { Uña de gato }\end{array}$ & $\mathrm{N}$ & Sh & 54.5 & 3 & - \\
\hline $\begin{array}{l}\text { Corynabutilon bicolor (Phil. ex K. Schum.) } \\
\text { Kearney } \\
\text { Malvaceae } \\
\text { Monte moro }\end{array}$ & $\mathrm{N}$ & Sh & 33.3 & - & Fodder \\
\hline $\begin{array}{l}\text { Lycium sp. } \\
\text { Solanaceae } \\
\text { Monte negro }\end{array}$ & $\mathrm{N}$ & Sh & 27.3 & - & - \\
\hline $\begin{array}{l}\text { Berberis microphylla G. Forst. }{ }^{*} \\
\text { Berberidaceae } \\
\text { Calafate }\end{array}$ & $\mathrm{N}$ & Sh & 27.3 & 3 & $\begin{array}{l}\text { Food, fodder, } \\
\text { dyes }\end{array}$ \\
\hline $\begin{array}{l}\text { Senecio filaginoides DC } \\
\text { Asteraceae } \\
\text { Charcao }\end{array}$ & $\mathrm{N}$ & Sh & 24.2 & - & - \\
\hline $\begin{array}{l}\text { Stillingia patagonica (Speg.) Pax and } \mathrm{K} \text {. } \\
\text { Hoffm. } \\
\text { Euphorbiaceae } \\
\text { Mata perro }\end{array}$ & $\mathrm{N}$ & Sh & 24.2 & - & - \\
\hline $\begin{array}{l}\text { Ochetophila trinervis (Gillies ex Hook. } \\
\text { and Arn.)* } \\
\text { Rhamnaceae } \\
\text { Chacai }\end{array}$ & $\mathrm{N}$ & Sh & 21.2 & 3 & - \\
\hline Baccharis salicifolia (Ruiz and Pav.) Pers. & $\mathrm{N}$ & Sh & 18.2 & - & - \\
\hline
\end{tabular}




\begin{tabular}{|c|c|c|c|c|c|}
\hline \multicolumn{6}{|l|}{ Asteraceae } \\
\hline \multicolumn{6}{|l|}{ Chilca } \\
\hline \multicolumn{5}{|l|}{ Chuquiraga avellanedae Lorentz } & \multirow[t]{3}{*}{ Medicine } \\
\hline Asteraceae & $\mathrm{N}$ & Sh & 18.2 & - & \\
\hline \multicolumn{5}{|l|}{ Trallao } & \\
\hline Prosopis denudans var. patagonica & $\mathrm{N}$ & Sh & 15.2 & 3 & Fodder \\
\hline \multicolumn{6}{|l|}{ Benth. (Speg.) Burkart* } \\
\hline \multicolumn{6}{|l|}{ Fabaceae } \\
\hline \multicolumn{6}{|l|}{ Algarrobillo } \\
\hline Retanilla patagonica (Speg.) Tortosa* & $\mathrm{N}$ & Sh & 15.2 & 6.1 & Fodder \\
\hline \multicolumn{6}{|l|}{ Rhamnaceae } \\
\hline \multicolumn{6}{|l|}{ Barba chivo } \\
\hline Prunus cerasus L.* & $\mathrm{E}$ & 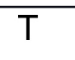 & 9.1 & 3 & Food, provision of \\
\hline Rosaceae & & & & & shelter \\
\hline \multicolumn{6}{|l|}{ Guindo } \\
\hline Salix humboldtiana Willd* & $\mathrm{N}$ & $\mathrm{T}$ & 9.1 & 6.1 & Provision of \\
\hline Salicaceae & & & & & shelter, structural \\
\hline Sauce común & & & & & materials \\
\hline Adesmia volckmanni Phil.* & $\mathrm{N}$ & Sh & 6.1 & 3 & Structural \\
\hline Fabaceae & & & & & materials \\
\hline \multicolumn{6}{|l|}{ Mamuel choique } \\
\hline Malus domestica Borkh. & $E$ & $T$ & 6.1 & - & Food, provision of \\
\hline Rosaceae & & & & & shelter \\
\hline \multicolumn{6}{|l|}{ Manzano } \\
\hline Azorella monantha Clos & $\mathrm{N}$ & Sh & 6.1 & - & - \\
\hline \multicolumn{6}{|l|}{ Apiaceae } \\
\hline \multicolumn{6}{|l|}{ Leña de piedra } \\
\hline Salix viminalis L. & $E$ & $\mathrm{~T}$ & 3.0 & - & - \\
\hline \multicolumn{6}{|l|}{ Salicaceae } \\
\hline \multicolumn{6}{|l|}{ Sauce mimbre } \\
\hline $\begin{array}{l}\text { Schinus patagonicus (Phil.) I.M. Johnst. } \\
\text { ex Cabrera. }\end{array}$ & $\mathrm{N}$ & Sh & 3.0 & - & - \\
\hline \multicolumn{6}{|l|}{ Anacardiaceae } \\
\hline \multicolumn{6}{|l|}{ Laura } \\
\hline Atriplex lampa (Moq.) D. Dietr. & $\mathrm{N}$ & Sh & 3.0 & - & - \\
\hline \multicolumn{6}{|l|}{ Chenopodiaceae } \\
\hline \multicolumn{6}{|l|}{ Sampa } \\
\hline Ephedra ochreata Miers & $\mathrm{N}$ & Sh & 3.0 & - & Medicine \\
\hline \multicolumn{6}{|l|}{ Ephedraceae } \\
\hline \multicolumn{6}{|l|}{ Silupe } \\
\hline Fabiana imbricata Ruiz and Pav. & $\mathrm{N}$ & Sh & 3.0 & - & - \\
\hline \multicolumn{6}{|l|}{ Solanaceae } \\
\hline Palo piche & & & & & \\
\hline
\end{tabular}




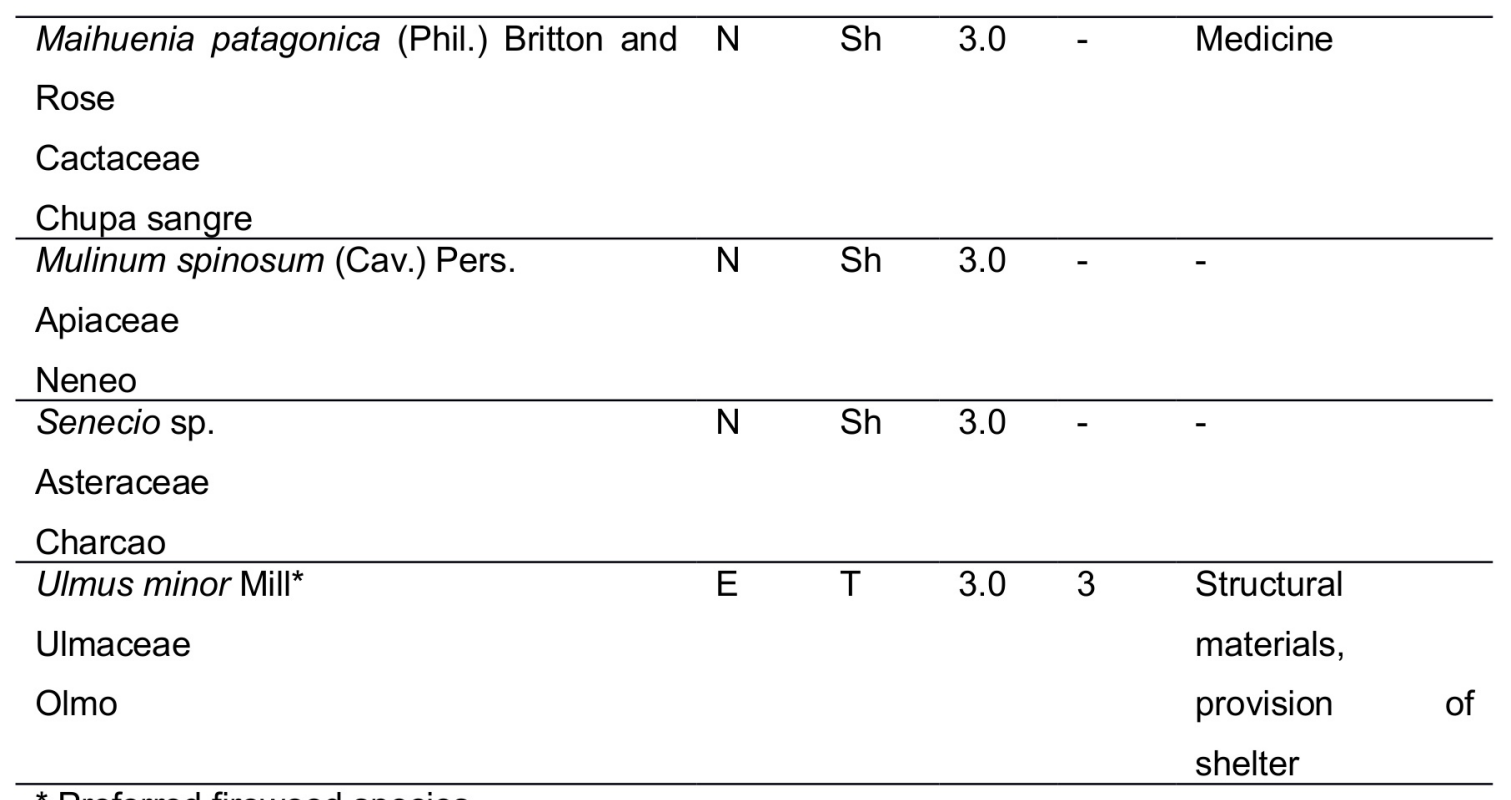

${ }^{\text {* } \text { Preferred firewood species }}$

highest values for use consensus (Table 1). Other highly preferred firewood plants are the exotic trees, due to their easy accessibility and availability; $P$. alba as part of domestic forestation, and Salix sp., an invasive species that grows on riversides

The reasons given by informants for this preference is their high calorific value, longlasting embers, ease of gathering and low smoke emission. Another important factor is their history of continuity of use since childhood.

\section{Ecological profile of preferred firewood species}

The firewood plants chosen by inhabitants present a high proportion of ecological persistence traits, which favour natural regeneration following biomass removal. For example, $43 \%$ of the species used for firewood have predominantly vegetative regeneration. Another important advantage of some of these firewood plants in the face of continuous cutting pressure is their wide geographical distribution $(36 \%$ of all the species), which shows the importance of their ability to adapt to different growing conditions, even in soils with specific problems like salinity and flooding. Finally, nitrogen fixation capacity was registered (18\% of all the species) (Figure 2).

\section{Alternative uses of preferred firewood species}

Of the preferred firewood plants used by Costa del Lepá and Gualjaina communities, $83 \%$ afford other uses or alternative products apart from calorific value, such as medicines, food, fodder and structural materials (posts and poles) (Table 1).

The exotic species $U$. minor "olmo" and $P$. cerasus, and the native $S$. humboldtiana presented, on average, the highest use versatility values $(U V=2)($ Table 1$)$.

The most significant alternative uses mentioned for the preferred species were fodder (leaves and tender stems of $B$. microphylla, Salix sp., $R$. patagonica, $S$. johnstonii and $P$. denudans var. patagonica, $41.7 \%$ ), structural materials (posts, poles 
and struts of Salix sp., S. humboldtiana, $P$. alba, U. minor and A. volckmanni, 33.3\%) and provision of shelter from the wind and cold (U. minor, Salix sp., $P$. cerasus, $P$. alba and $S$. humboldtiana, $33.3 \%$ ). To a lesser extent other uses were mentioned (i.e.,, fruit of $B$. microphylla, $P$. cerasus and $S$. johnstonii, 25\%), medicine (B. microphylla and S. johnstonii, 16.7\%) and dyes (S. johnstonii and B. microphylla, 16.7\%).

It is worthy of note that all preferred plants are melliferous, an aspect which, although not mentioned by informants in interviews, is of increasing interest amongst the local rural communities of the Patagonian steppe in Chubut province, due to its productive potential. This activity could generate income in its development phase, before being cut for firewood.

\section{Integral analysis of total firewood species cited by informants}

Four general groups were identified from the correspondence analysis, considering both firewood species mentioned by informants, and ecological and ethnobotanical variables (Figure 2).

The first two axes explained $31.5 \%$ of the total inertia. The first group was distinguished by native nitrogen fixing preferred species with low availability ( $A$. volckmanni, $P$. denudans var. patagonica and $R$. patagonica); the second group was made up of native preferred firewood species with high calorific value, low smoke emission and low ash production ( $S$. humboldtiana, B. microphylla, O. trinervis and $S$. johnstonii); the third group was defined by exotic tree species with predominantly vegetative reproduction, wide geographical distribution and high use versatility values (U. minor, $P$. cerasus, Salix sp., $P$. alba and $M$. domestica), and the last group was represented by less-preferred native shrub species with low calorific value, high smoke emission, high ash production, low versatility, seed reproduction and restricted geographical distribution ( $A$. monantha, Lycium sp., $C$. bicolor, $C$. avellanedae, S. patagonica, N. axillaris and $S$. filaginoides).

\section{DISCUSSION}

The significant role played by native firewood species concurs with findings in other parts of the world, demonstrating the importance of a history of use in common with the natural landscape (Arre et al. 2015; Ramos et al. 2008; Szymañski 2012, Sharma and Samant 2014). Quintana (2015) has described the 120 most abundant species in the arid Patagonia of Chubut province, of which 60 are woody shrubs. Our results reflect that $40 \%$ of this richness is being used as firewood in these two populations. Furthermore, this richness of firewood species was similar to that found in other studies carried out in rural communities situated in arid and semiarid areas of the Patagonian region (Cardoso et al. 2012; Cardoso et al. 2017).

Firewood species preference criteria found in this study have also been recorded for other populations throughout the world (May 2013; Quiroz-Carranza and Orellana 2010; Ramos et al. 2008). The criteria specified here by locals correspond to attributes that characterise the preferred firewood species, and distinguish them from the species actually used, which are generally more readily available in the surroundings. Although this work did not analyse abundance of used or preferred species, preference according to the local vision appears to depend mainly on cultural attributes. 
The species $S$. johnstonii is the most preferred plant for use as firewood, due to its high calorific value and production of longlasting embers. Appreciation of this species has been documented in archaeobotanical studies (Ancibor and Pérez de Micou 1995; Ciampagna and Caparelli 2012) and in work recently carried out in other populations of Extra-Andean Patagonia (Cardoso et al. 2015). However, the current low level of abundance and availability of this native species, as with other species, such as $R$. patagonica "barba chivo" and $P$. denudans var. patagonica "algarrobillo", are limiting factors since these species are subject to high use pressure and/or found on private land where access is legally forbidden by owners.
The group of plants used is distinguished by a high proportion of species with predominantly vegetative reproduction and extensive geographical distribution.

Almost half of the species used for firewood present vegetative regeneration, an important aspect in terms of response to environmental disturbance such as firewood extraction (Abbot and Lowore 1999; Blackhall et al. 2008; Damascos et al. 1999; Raffaele et al. 2011). This factor is fundamental for recovery of the ecosystem, making re-establishment of populations of firewood species possible following biomass removal.

Kuzovkina and Quigley (2005) also found that in the case of $P$. alba and Salix sp., the new ramifications produced in response to

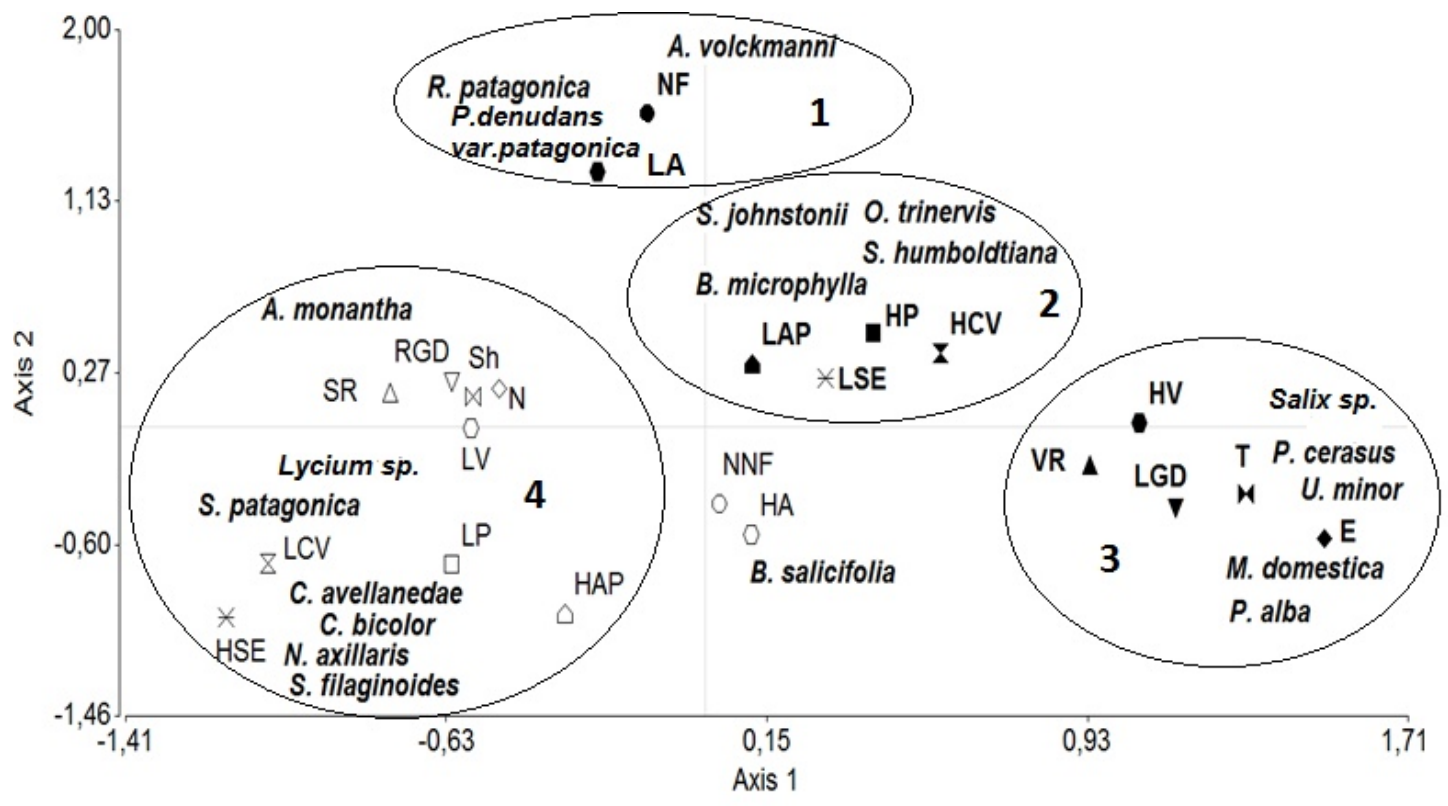

Figure 2. Correspondence analysis according to botanical-ecological and cultural attributes of firewood species used by the Costa del Lepá and Gualjaina communities, Patagonia, Argentina. Abbreviations $=\triangle N=$ native, $\bullet E=$ exotic, $\ S h=$ shrub, $\boldsymbol{\text { M }} T=$ tree, $\Delta \mathrm{VR}=$ vegetative reproduction, $\triangle S R=$ seed reproduction, $\bullet N F=$ nitrogen fixation, $\circ N N F=$ non nitrogen fixating, $\boldsymbol{\nabla L G D =}$ large geographical distribution, $\mathbf{\nabla R G D}=$ restricted geographical distribution, $\bullet \mathrm{HP}=$ high preference, $\square \mathrm{LP}=$ low preference, $\mathrm{HV}=$ high versatility, $\square \mathrm{LV}=$ low versatility, $\mathbf{\mathrm { HCV }}=$ high calorific value, $\mathrm{ZLCV}=$ low calorific value, $\triangle \mathrm{HAP}=$ high ash production,

LAP = low ash production, $\triangle \mathrm{HA}=$ high availability, a LA= low availability, $*$ HSE=high smoke emission, $*$ LSE= low smoke emission, $1=$ first group; 2=second group; $3=$ third group; $4=$ fourth group. 
cutting, especially during winter and the beginning of spring, stimulate rapid recovery of the soil. This accelerates the recuperation of damaged ecosystems, decreases the problem of soil erosion and favours the physical and nutritional condition of the soil.

In addition, nitrogen $(\mathrm{N})$ is one of the most limiting nutrients in arid and semi-arid zones (Bolton et al. 1990). The $\mathrm{N}$ in the soil can be altered by disturbances occasioned by use of firewood plants, overgrazing or other factors, which alter the equilibrium of soil processes and the environment, leading to nitrogen loss. Therefore, in order to ensure the availability and contribution of $\mathrm{N}$ to the soil, symbiosis of the plants with bacteria is important. This is the case with the firewood species of the Rhamnaceae and Fabaceae families (Table 1), which can contribute to recuperation of the structure and function of the ecosystem. In particular, diverse studies have been carried out on the association between $O$. trinervis and the bacteria Frankia for $\mathrm{N}$ fixation, and its vital importance for circulation of $\mathrm{N}$ and recuperation of degraded soils in the Patagonian region (Reyes et al. 2011). All these traits allow wide, diverse human use of the landscape and distribution of gathering pressure over different sites, favouring a use strategy of rotation and resting of the plant populations.

The plants are not only used for firewood, however, but also for other purposes. Utilitarian versatility in firewood species was also a characteristic recorded in other rural communities, and other use categories (Richeri et al. 2013; Tabuti et al. 2003). This demonstrates not only depth of knowledge and application, but also the very varied significance of woody plants for inhabitants. The plants are used to sustain everyday life, in different contexts and at different times, bestowing an adaptive quality on this set of species in the lives of these populations. This adaptive, integral, flexible character of the LEK components has long been noted in the literature as an aspect to be applied in the autonomous management of common resources in rural communities (Ostrom 2002).

The grouping pattern of firewood species showed in Figure 2 reflects the wide range of biocultural characteristics of the plants used by inhabitants, in relation to higher or lower use preference. Evaluation of these characteristics in association with local preferences, and their implications for conservation have also been recognised in diverse studies on energy plantations (Abbot and Lowore 1999; May 2013; Tabuti et al. 2003; Yao and Bae 2008). According to these results, a reduction in the impact caused by continuous extraction of wild wood can be achieved by the farming and management of plants from the second and third groups, containing the firewood species which are preferred due to their desirable combustion characteristics.

Group 1 species form a special group of native plants that suffer great pressure of use, and low availability. This appears to be the most threatened group, which should be under management through in situ practices designed to recover and restore these populations, and should also be considered for ex situ forestry practices. The focus of home plantations should therefore be on the second group, since it represents the species with high preference and high yield which are still available in the environment. However, as group 2 contains mostly native species, there are likely to be limitations in terms of vegetative reproduction (highly specific habitat requirements) and slower growth. In order to minimize this problem and promote dynamic, rapid and versatile production, the species of group 3 should be 
included and used in association with the target second group. Group 3 is made up of exotic species with high reproductive capacity, rapid growth and versatile use, and could provide continuous resources (i.e.,, Salix sp., P. alba, U. minor).

Together, therefore, these plants could offer multiple benefits, such as the recovery of edaphic fertility, amelioration of extreme climatic conditions and reduction of erosion. It should be noted that the species of groups 1 and 2 are nitrogen-fixing plants, such as $P$. denudans var. patagonica, $O$. trinervis, $A$. volckmanni and $R$. patagonica. These species are capable of becoming established and growing on substrates of poor quality, tolerating factors of extreme stress (hydric deficit, compacted soil salinity, etc.) and may even favour substrate rehabilitation. The nitrogen fixing species in particular are very important in the context of rapid recovery of degraded ecosystems and natural regeneration (Ferrari and Wall 2004).

\section{CONCLUSIONS}

Based on these results, it is recommended that installation of firewood plantations and peridomestic forest plantations be implemented, using the species named in groups 2 and 3 , including both native and exotic species. These species all possess long lasting cultural significance; they constitute substantial elements in locals' homes, and they represent the energy that drives their activities, such as the preparation of meals and heating of the house, providing warmth for the family.

Moreover, given the multipurpose nature of these species, it is important to design a management strategy for them, tending towards gradual and diversified use of the products in different stages of their development, which could thus provide a wide range of services to rural communities. It would therefore be necessary to carry out, with the community, further studies on the ecological characteristics and methods of use (i.e., quantities, parts to be used) of these firewood species of great cultural importance.

We consider that the implementation of peridomestic plantations for the provision of energy, containing the species highlighted in this work and complemented by other fastgrowing trees which are provided by state organisations (i.e.,, INTA: National Institute of Agricultural Technology; CORFO: Chubut Promotion Corporation) (Cardoso and Ladio 2011), would diminish gathering pressure on native species in the wild, and allow families to have easier access to these vital resources, which in most cases currently require searches over long distances.

It is essential to consider these intercultural points of view when planning the implementation of firewood plantations of native and exotic species in rural and/or indigenous communities. Sustainable management of firewood resources could be effective if general community use is guaranteed, as well as participation of the communities affected, so as to provide mechanisms of self-government with truly democratic control, giving equal access to everyone and vitality to the shared resource.

Finally, we underline the fact that integration of local and scientific knowledge can enrich our views on firewood resource management and generate appropriate, locally specific strategies that can contribute to the self-sufficiency of rural communities in Patagonia. 


\section{ACKNOWLEDGEMENTS}

We are deeply grateful to the inhabitants of Costa del Lepá and Gualjaina communities for their willingness to help, and for sharing their knowledge and experience. Our thanks also go to the anonymous reviewers whose suggestions enabled us to improve this work. This study was funded by PICT 2012-1073 of the Agencia Nacional de Promoción Científica y Tecnológica (ANPCyT) and by Consejo Nacional de Investigaciones Científicas y Técnicas (CONICET-PIP 0644).

\section{REFERENCES}

Abbot P, Lowore J (1999) Characteristics and management potential of some indigenous firewood species in Malawi. Forest Ecology and Management 119: 111-121.

Aigo J, Ladio A (2016) Traditional Mapuche ecological knowledge in Patagonia, Argentina: fishes and other living beings inhabiting continental waters, as a reflection of processes of change. Journal of Ethnobiology and Ethnomedicine 12: 56.

Ancibor E, Pérez de Micou C (1995) Identification of firewood species in the archaeological record of the Patagonian Steppe. Journal Ethnobiology 15(2): 189-200.

Armesto J, Smith-Ramirez C, Rozzi R (2001) Conservation strategies for biodiversity and indigenous people in Chilean forest ecosystems. Journal of the Royal Society of New Zealand 31: 865-877.

Arre J, Molares S, Ladio A, Kutschker A (2015) Etnobotánica de las plantas leñateras y su circuito comercial en una ciudad de la Patagonia Argentina. Gaia Scientia 9: 41-48.

Barchuk A, Campos E, Oviedo C, Diaz M (2006) Supervivencia y crecimiento de plántulas de especies leñosas del Chaco Árido sometidas a remoción de la biomasa aérea. Ecologia Austral 47-61.
Berkes F (1999) Sacred Ecology. Traditional Ecological Knowledge and Resource Management. Taylor and Francis, Philadelphia.

Blackhall M, Raffaele E, Veblen T (2008). Cattle affect early post-fire regeneration in a Nothofagus dombeyi - Austrocedrus chilensis mixed forest in northern Patagonian Argentina. Biological Conservation 2251-2261.

Bolton H, Smith J, Wildung R (1990) Nitrogen mineralization potentials of shrub-steppe soils with different disturbance histories. Soil Science Society of America Journal 54: 887-891.

Cardoso B, Ladio A (2011) Forestación peridoméstica en Patagonia y conocimiento ecológico tradicional: un estudio de caso. Sitientibus Série Ciencias Biológicas 11(2): 321-327.

Cardoso B, Ladio A, Lozada M (2012) The use of firewood in a Mapuche community in a semi-arid region of Patagonia, Argentina. Biomass and Bioenergy 46(2012): 155-164.

Cardoso B, Ladio A, Dutrus S, Lozada M (2015) Preference and calorific value of fuelwood species in rural populations in northwestern Patagonia. Biomass and Bioenergy 81: 514-520.

Cardoso B, Ladio A, Lozada M (2017) Niche breadth and redundancy: Useful indices to analyse fulwood use in rural communities. Journal of Arid Environments 1-8.

Chettri N, Sharma E (2007) Firewood value assessment: A comparison on local preference and wood constituent properties of species from a trekking corridor, West Sikkim, India. Current Science 92: 1744-1747.

Ciampagna M, Capparelli A (2012) Historia del uso de las plantas por parte de las poblaciones que habitaron la Patagonia Continental Argentina. Revista de arqueología 6: 45-75. 
Citarella L (1995) Medicinas y Culturas en La Araucanía. Sudamericana, Santiago, Chile.

Correa M N (1971) Flora patagónica. Parte VII. Compositae. Colección científica del INTA. Bs. As., $451 \mathrm{pp}$

Correa M N (1984) Flora patagónica. Parte IVa. Dicotiledóneas Dialipétaleas (Salicaceae a Cruciferae). Colección Científica del INTA. Bs. As., 559 pp.

Damascos M, Ghermandi L, Ladio A (1999) Persistence of the native species of a patagonian Austrocedrus chilensis forest in Bariloche, Argentina. International Journal of Ecology and Environmental Sciences 25: 21-22.

Di Rienzo J, Casanoves F, Balzarini M, Gonzalez L, Tablada M, Robledo C (2016) Grupo InfoStat FCA. Universidad Nacional de Córdoba Argentina.

[http=//www.infostat.com.ar] Accessed June 2016.

ECPI Encuesta Complementaria de Pueblos Indígenas (2007) [http://www.indec.gob.ar/] Accessed December 2015.

Ferrari AE, Wall LG (2004) Utilización de árboles fijadores de nitrógeno para la revegetación de suelos degradados. Revista de la Facultad de Agronomía 105 (2): 6387.

Finkelstein D, Méndez P (2008) Interculturalidad $y$ arte textil como símbolo de identidad. Actas IX Congreso Argentino de Antropología Social, Facultad de Humanidades y Ciencias Sociales, Universidad Nacional de Misiones, Posadas.

Gómez-Baggethun E, Reyes-García V, Olsson P, Montes C (2012) Traditional ecological knowledge and community resilience to environmental extremes: A case study in Doñana, SW Spain. Global Environmental Change 22(3): 640-650.

Gunderson L, Holling C (2002) Panarchy: Understanding Transformations in Human and Natural Systems. Island Press, Washington.
INDEC Instituto Nacional de Estadística y Censos (2010) [http://www.indec.gob.ar/] Accessed December 2015.

Izquierdo F, Velazco V, Abdel N (2009) Montes leñeros y cortinas de reparo en la región sur de Río Negro. 1 ed. Boletín de divulgación INTA, Buenos Aires.

Kebede A, Chimdi A, Nair A (2015) Effect of Firewood Energy Consumption of Households on Deforestation in Debis Watershed Ambo District, Oromia Regional State, Ethiopia. World Applied Sciences Journal 33 (7): 1154-1163.

Kuzovkina Y, Quigley M (2005) Willows beyond wetlands: uses of Salix $L$. species for environmental projects. Water, Air, and Soil Pollution 162: 183-204.

Ladio A (2013) Mapuche Resilience and Adaptation to Arid Uplands in NW Patagonia, Argentina. In: Continuity and Change in Cultural Adaptation to Mountain Environments. Springer New York, pp. 259273.

Ladio A, Lozada M (2004) Patterns of use and knowledge of wild edible plants from distinct ecological environments: a case study of a Mapuche community from NW Patagonia. Biodiversity and Conservation 13: 1153-1173.

Ladio A, Molares S (2016) Etnoconservacionismo y prácticas locales en Patagonia: avances $y$ perspectivas. In: Casas A, Torres-Guevara $J$, Parra $F$ (eds) Domesticación en el Continente Americano. Historia y perspectivas del manejo de recursos genéticos en el Nuevo Mundo. Universidad Agraria La Molina. IIES, Lima, Perú, pp. 649672.

Maffi L (2001) Introduction on the interdependence of biological and cultural diversity. In: Maffi L (ed.) Biocultural diversity. Linking language, knowledge, and the environment. Smithsonian Inst., Washington, pp 1-50. 
May T (2013) Plantas preferidas para leña en la zona de bosque seco de Pedro Santana y Bánica, República Dominicana. Aspectos etnobotánicos y de manejo sustentable. Ambiente y Desarrollo 17(33): 7185.

Mereb M (1990) Caracterización climatológica de los valles superior y medio del río Chubut. Dirección general de estudios y proyectos. Hidrometeorológico principal. Ministerio de economía, obras y servicios públicos, Chubut.

Molares S, Ladio A (2012) Mapuche perceptions of Andean Nothofagus forests and their medicinal plants: a case study from a rural community in Patagonia, Argentina. Biodiversiy and Conservation 21: 1079-1093.

Nuñez M A, Raffaele E (2007). Afforestation causes changes in post-fire regeneration in native shrubland communities of northwestern Patagonia. Journal of Vegetation Science 18: 827-834.

Ostrom E (2002) Common-pool resources and institutions: toward a revised theory. Handbook of Agricultural Economics 2: 1315-1339.

Pérez-Ruiz L, Argueta-Villamar A (2011) Saberes indígenas y diálogo intercultural. Cultura y saberes locales 31-56.

Phillips O, Gentry A (1993) The useful plants of Tambopata, Peru: I. Statistical hypothesis test with a new quantitative Technique. Economic Botany 47: 15-32.

Quintana D (2015) Plantas de la Patagonia árida, nativas y exóticas del noreste del Chubut. 1 ed. Remitente Patagonia, Trelew, Chubut, Argentina.

Quiroz-Carranza J, Orellana R (2010) Uso y manejo de leña combustible en viviendas de seis localidades de Yucatán, México. Madera y Bosques 16(2): 47-67.

Ramos M, Medeiros P, Almeida A, Feliciano A, Albuquerque $U$ (2008) Can wood quality justify local preferences for firewood in an area of Caatinga vegetation? Biomass and Bioenergy 32: 503-509.
Raffaele E, Veblen T, Blackhall M, TerceroBucardo N (2011) Synergistic influences of introduced herbivores and fire on vegetation change in northern Patagonia, Argentina. Journal of Vegetation Science 22: 59-71.

Reyes F, Gobbi M, Chaia E (2011) Reproductive ecology of Ochetophila trinervis in Northwest Patagonia. Functional Plant Biology 38: 720-727.

Richeri M, Cardoso B, Ladio A (2013) Soluciones locales y flexibilidad en el conocimiento ecológico tradicional frente a procesos de cambio ambiental: estudios de caso en Patagonia. Ecología Austral 23: 184-193.

Sharma P, Samant S (2014) Assessment of fuel resource diversity and utilization pattern in Nargu Wildlife Sanctuary of Himachal Pradesh, NW Himalaya. International Journal of Biodiversity and Conservation 6: 17-27.

Szymañski A (2012) Evaluación ambiental y propuesta de manejo para el uso leñero y ganadero en un área de amortiguación del Parque Nacional Lanín en tierras de la Comunidad Mapuche Aigo. Tesis de grado, Universidad Nacional de Cuyo.

Tabuti J, Dhilliona S, Lyea K (2003) Firewood use in Bulamogi County, Uganda: species selection, gathering and consumption patterns. Biomass and Bioenergy 25: 581 - 596.

Tengö M, Brondizio ES, Elmqvist T, Malmer $\mathrm{P}$, Spierenburg M (2014) Connecting diverse knowledge systems for enhanced ecosystem governance: The multiple evidence base approach. Ambio 43(5): 579-591.

Toledo V (1992) What is ethnoecology? Origins, scope and implications of a rising discipline. Etnoecologica 1: 5-21.

Trillo C, Colantonio S, Galetto L (2014) Perceptions and Use of Native Forests in the Arid Chaco of Córdoba, Argentina. Ethnobotany Research and Applications 12: 497510 
Vandebroek I, Reyes-García V, Albuquerque U, Bussmann R, Pieroni A (2011) Local knowledge: Who cares? Journal of Ethnobiology and Ethnomedicine 7(35).
Yao C, Bae K (2008) Firewood Plantation as an alternative source of energy in the Philippines. Journal of Forest and Environmental Science 24(3): 171-174.
Received: 05 February 2017

Accepted: 18 April 2017

Published: 10 August 2017 